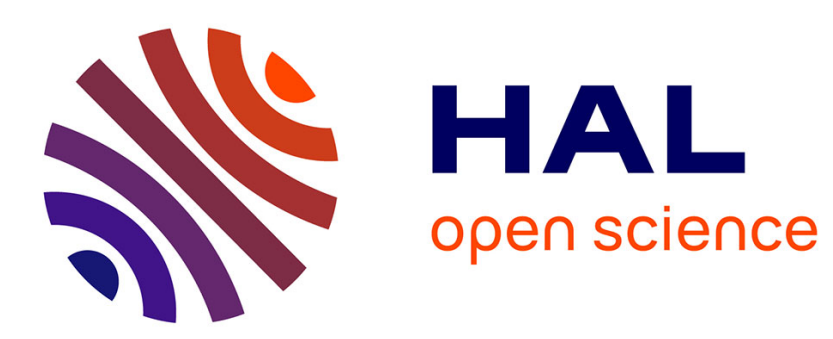

\title{
Photosystem II repair in marine diatoms with contrasting photophysiologies
}

Johann Lavaud, Christophe Six, Douglas A Campbell

\section{To cite this version:}

Johann Lavaud, Christophe Six, Douglas A Campbell. Photosystem II repair in marine diatoms with contrasting photophysiologies. Photosynthesis Research, 2016, 127 (2), pp.189-199. 10.1007/s11120015-0172-3 . hal-01176261

\section{HAL Id: hal-01176261 \\ https://hal.sorbonne-universite.fr/hal-01176261}

Submitted on 15 Jul 2015

HAL is a multi-disciplinary open access archive for the deposit and dissemination of scientific research documents, whether they are published or not. The documents may come from teaching and research institutions in France or abroad, or from public or private research centers.
L'archive ouverte pluridisciplinaire HAL, est destinée au dépôt et à la diffusion de documents scientifiques de niveau recherche, publiés ou non, émanant des établissements d'enseignement et de recherche français ou étrangers, des laboratoires publics ou privés. 


\section{Photosystem II repair in marine diatoms with contrasting photophysiologies}

Johann Lavaud $^{1 H_{*} *}$, Christophe $\mathrm{Six}^{2,3,4 \#}, \&$ Douglas A. Campbell ${ }^{2}$

${ }^{1}$ UMR 7266 'LIENSS', CNRS / University of La Rochelle, Institute for Coastal Research and Environment (ILE), 2 rue Olympe de Gouges, 17000 La Rochelle cedex, France

${ }^{2}$ Department of Biology, Mount Allison University, Sackville, NB E4L 1G7, Canada

${ }^{3}$ Centre National pour la Recherche Scientifique (CNRS), UMR 7144 'Adaptation et Diversité en Milieu Marin', 'Marine Phototrophic Prokaryotes' group, Station Biologique de Roscoff, Place George Teissier, 29680 Roscoff, France

${ }^{4}$ Université Pierre et Marie Curie (Paris 06), UMR 7144 'Adaptation et Diversité en Milieu Marin', 'Marine Phototrophic Prokaryotes' group, Station Biologique de Roscoff, Place George Teissier, 29680 Roscoff, France

\# these two authors equally contributed to the work.

* Corresponding author: Johann Lavaud

Mailing address: UMR7266 'LIENSs', CNRS/Université de La Rochelle, Institut du Littoral et de l'Environnement, 2 rue Olympe de Gouges, 17000 La Rochelle Cedex, France; Phone: $\quad+33-(0) 5-46-50-76-45 ; \quad$ Fax: $\quad+33-(0) 5-46-45-82-64 ; \quad$ Email: johann.lavaud@univ-lr.fr 


\section{Acknowledgements}

This work was supported by the CNRS-Centre National de la Recherche Scientifique (for JL), the European Community FP7-PEOPLE-2010-IRSES (n²69294) BIOVADIA (for JL), and by the Canada Research Chairs (for CS and DC). Equipment for photophysiology and protein analyses was funded by the Canada Innovation Foundation, the New Brunswick Innovation Foundation and the Natural Sciences and Research Council of Canada (DC). 


\begin{abstract}
S. costatum and P. tricornutum are model marine diatoms with differing strategies for non-photochemical dissipation of excess excitation energy within photosystem II (PSII). We showed that $S$. costatum, with connectivity across the pigment bed serving PSII, and limited capacity for induction of sustained non-photochemical quenching (NPQ), maintained a large ratio of $\left[\mathrm{PSII}_{\mathrm{Total}}\right] /\left[\mathrm{PSII}_{\mathrm{Active}}\right]$ to buffer against fluctuations in light intensity. In contrast, $P$. tricornutum, with a larger capacity to induce sustained NPQ could maintain a lower $\left[\mathrm{PSII}_{\mathrm{Total}}\right] /[\mathrm{PSII} \mathrm{Active}]$. Induction of NPQ was correlated with an active PSII repair cycle in both species, and inhibition of chloroplastic protein synthesis with lincomycin lead to run away over-excitation of remaining PSII $_{\text {Active, }}$ particularly in S. costatum. We discuss these distinctions in relation to the differing capacities, induction and relaxation rates for NPQ, and as strain adaptations to the differential light regimes of their originating habitats. The present work further confirms the important role for the light-dependent fast regulation of photochemistry by NPQ interacting with PSII repair cycle capacity in the ecophysiology of both pennate and centric diatoms.
\end{abstract}

Key words: diatoms; ecophysiology; photoprotection; non-photochemical fluorescence quenching; PsbA (D1) protein; Photosystem II repair.

Abbreviations: Chl $a$, Chlorophyll $a$; DD, diadinoxanthin; DT, diatoxanthin; $\Delta \mathrm{pH}$, transthylakoidal proton gradient; $\mathrm{F}_{\mathrm{V}} / \mathrm{F}_{\mathrm{M}}$, maximum quantum yield of Photosystem II; $\mathrm{k}_{\mathrm{pi}}$, first order rate constant for photoinactivation of PSII; $\mathrm{k}_{\mathrm{Psba}}$, first order rate constant for removal of PsbA protein of PSII; LHC, light-harvesting complex; NPQ, non- 
photochemical Chl $a$ fluorescence quenching; PSII, Photosystem II; ФPSII, quantum yield of PSII electron transport; $\sigma_{\text {PSII }}$, effective absorbance cross section serving PSII photochemistry; $\sigma_{\mathrm{i}}$, effective absorbance cross section driving PSII photoinactivation; XC, xanthophyll cycle. 


\section{Introduction}

Diatoms are a major group of eukaryotic microalgae ubiquitous in all marine and freshwater ecosystems. With $>10^{5}$ species (Kooistra et al. 2007; Mock and Medlin 2012), they are among the most significant photosynthetic organisms. They contribute to about $40 \%$ of the aquatic primary production making them essential for most marine food-webs (Armbrust 2009). Their contribution to several biochemical cycles (Tréguer and De La Rocha 2013; Sarthou et al. 2005) and unique biological, physiological and metabolic characteristics (Consalvey et al. 2004; Armbrust 2009; Mock and Medlin 2012; Obata et al. 2013; Lyon and Mock 2014; Wilhelm et al. 2014) contribute significantly to shaping the functions of contemporary oceans (Kooistra et al. 2007; Mock and Medlin 2012). As with most microalgae (MacIntyre et al. 2000), the photosynthetic productivity of diatoms strongly depends on the light climate (Depauw et al. 2012; Wilhelm et al. 2014). Planktonic as well as benthic diatoms tend to dominate ecosystems (i.e. coasts and estuaries) where the light climate is characterized by unpredictable high-frequency, large amplitude fluctuations in irradiance. Depending on light attenuation throughwater, ice or sediment, on the rate of water mixing, on the tidal cycle, and on the daily/seasonal changes of solar irradiation, diatoms can be exposed to episodic or chronic excess light, possibly generating stressful conditions that impair their photosynthetic efficiency and their productivity through photoinhibition (Blanchard et al. 2004; Lavaud et al. 2007; Wu et al. 2011; Wu et al. 2012).

In order to limit such situations, diatoms have evolved fast regulatory biological and physiological processes which comprise a 'photoprotective network' (Consalvey et al. 2004; Lavaud and Goss 2014; Wilhelm et al. 2014; Barnett et al. 2015; Laviale et al. 
2015). They may 1) actively escape from excess light through motility, at least in benthic motile diatoms that inhabit the sediments of intertidal flats, 2) safely dissipate the excess of absorbed light energy, 2) balance the excess excitation energy within the photosynthetic apparatus and plastid, 3) scavenge reactive oxygen species, 4) repair damage to proteins, thus containing and countering net photodamage to the photosynthetic and plastid machinery. In diatoms, one of these regulatory processes, believed to be essential, is the fast (i.e. seconds-scale timing) development of a thermal dissipation of excess energy that can be detected thanks to a non-photochemical quenching of chlorophyll $a(\mathrm{Chl} a$ ) fluorescence (NPQ) (Büchel 2014; Lavaud and Goss 2014). In diatoms, NPQ is controlled by i) the light-dependent build-up of the transthylakoidal proton gradient $(\Delta \mathrm{pH})$, ii) the $\Delta \mathrm{pH}$-dependent conversion of the xanthophylls diadinoxanthin (DD) into diatoxanthin (DT) called 'xanthophyll cycle' (XC) (Brunet and Lavaud 2010; Lavaud and Goss 2014), and iii) the presence of specific polypeptides of the light-harvesting complex (LHC) antenna named Lhcx (Depauw et al. 2012; Büchel 2014). Recently, a working mechanistic model for diatom NPQ has been proposed (see Chukhutsina et al. 2014; Lavaud and Goss 2014; Derks et al. 2015; Goss and Lepetit 2015) with two mechanistic and kinetic quenching components (namely Q1 and Q2).

By significantly contributing to the cellular response under fluctuating light conditions (Wagner et al. 2006; Mills et al. 2010; Giovagnetti et al. 2014), NPQ is critical for maintaining the photosynthetic efficiency of both planktonic and benthic diatoms (Lavaud and Goss 2014; Barnett et al. 2015; Laviale et al. 2015). An increasing number of reports suggest that diatom/microalgal inter-species differences in NPQ are involved in 
the differential colonization of marine habitats based on the light climate combined or not with other environmental factors including nutrients, temperature, and salinity (Strzepek and Harrison 2004; Lavaud et al. 2007; Dimier et al. 2007; Kropuenske et al. 2009; Bailleul et al. 2010; Mills et al. 2010; Petrou et al. 2011; van de poll et al. 2011; Wu et al. 2012; Lavaud and Lepetit 2013; Barnett et al. 2015; Juneau et al. 2015). Induction of NPQ nonetheless can impose opportunity costs upon microalgal productivity, since a sustained NPQ that persists after a downward shift in irradiance can lower achieved productivity at the new, lower light level (Raven 2011). In parallel to NPQ, capacities to repair the prime photosynthetic target of photodamage, the PsbA (D1) protein of photosystem II (PSII), was shown to differ among diatom species (Kropuenske et al. 2009; Key et al. 2010; Petrou et al. 2010; Wu et al. 2011; Wu et al. 2012; Campbell et al. 2013). In a series of previous studies (Lavaud et al. 2004, Lavaud et al. 2007; Lavaud and Lepetit 2013), we compared the photoprotective capacities and properties of two model marine diatom strains, Phaeodactylum triconutum and Skeletonema costatum. We related NPQ and xanthophyll differences (i.e. P. tricornutum $>$ S. costatum) to the differential light climates of the original habitats to which the strains were adapted (Lavaud and Lepetit 2013). We have not, however, to date, analyzed possible differential abilities to repair the PSII PsbA protein across these strains with differing photophysiologies (Wu et al. 2011; Wu et al. 2012).

For that purpose, we grew both strains under low light (LL-50 $\mu$ mol photons $\mathrm{m}^{-2}$ $\mathrm{s}^{-1}$ ) comparable to levels near the bottom of the photic zone, and then shifted both strains to moderate high light (HL-450 $\mu$ mol photons $\mathrm{m}^{-2} \mathrm{~s}^{-1}$ ) for $90 \mathrm{~min}$, an intensity equivalent to the top $30 \%$ of the photic zone and sufficient to induce significant 
photoinactivation/photoinhibition within a 90 min incubation (Lavaud et al. 2007). The HL incubations were in the presence or not of lincomycin, to inhibit the translation of chloroplast transcripts, notably $p s b A$, the gene encoding the PsbA protein. Lincomycin thereby efficiently blocks the PSII repair cycle in diatoms (Wu et al. 2011; Wu et al. 2012; Campbell et al. 2013) allowing us to separate primary photoinactivation of PSII from the counteracting PSII repair cycle and to analyze the interaction of these processes with inductions of NPQ mechanisms. The results showed that both diatoms showed a comparable primary susceptibility to photoinactivation of PSII (Key et al. 2010; Wu et al. 2011; Wu et al. 2012) but that S. costatum showed a higher total content of PSII to maintain significantly higher capacity for PSII repair, in contrast to P. tricornutum, which relies more upon induction of NPQ to allow a smaller pool of PSII.

\section{Material and Methods}

\section{Culturing and light treatments}

Exponential cultures $(500 \mathrm{~mL}$ ) grown in glass Erlenmeyer flasks ( $f / 2$ medium, $50 \mu \mathrm{mol}$ photons $\mathrm{m}^{-2} \mathrm{~s}^{-1}, 20^{\circ} \mathrm{C}$, air bubbling) were split into two polystyrene flasks. One was supplemented with $500 \mu \mathrm{g} \mathrm{mL}^{-1}$ lincomycin and both flasks were incubated in the dark for $10 \mathrm{~min}$, to allow the antibiotic to penetrate the cells and inhibit ribosome function. The two flasks were then shifted for $90 \mathrm{~min}$ to $450 \mu \mathrm{mol}$ photons $\mathrm{m}^{-2} \mathrm{~s}^{-1}$ (high light-HL) blue light (LEE Filter \#183, Panavision; 455-479 nm peak transmission, 406-529 nm half-height width). Samples were collected at 15, 30, 60 and 90 min to measure biophysical properties and for later protein immunodetection. The sub-cultures were then 
shifted back to their initial growth light $\left(50 \mu \mathrm{mol}\right.$ photons $\mathrm{m}^{-2} \mathrm{~s}^{-1}$, low light-LL) and sampled after 30,60 and 180 min of recovery.

\section{Chlorophyll a (Chl a) fluorescence measurements}

Culture aliquots were dark-adapted for $10 \mathrm{~min}$ and a blue-green modulated measuring light (4 Hz; Xenon-PAM, Walz, Effetrich, Germany) was activated to measure the basal fluorescence $\mathrm{F}_{0}$. A saturating white light pulse $\left(4,000 \mu \mathrm{mol}\right.$ photons $\left.\mathrm{m}^{-2} \mathrm{~s}^{-1}, 500 \mathrm{~ms}\right)$ was triggered in order to determine the maximal $\mathrm{Chl} a$ fluorescence level in the dark $\mathrm{F}_{\mathrm{M}}$. Actinic irradiance was then activated at HL level; after signal stabilisation $\left(\mathrm{F}_{\mathrm{S}}\right.$ level), a saturating light pulse was triggered to determine the light acclimated maximal fluorescence $\left(\mathrm{F}_{\mathrm{M}}{ }^{\prime}\right)$, and the actinic irradiance was briefly interrupted to measure $\mathrm{F}_{0}$ ' with PSII centers open in the light acclimated state. The PSII inhibitor 3-(3,4-dichlorophenyl)1,1-dimethylurea (DCMU) was then added and after signal stabilisation, a light pulse was triggered again to determine the maximal fluorescence $\mathrm{F}_{\mathrm{Mm}}$. This measurement protocol was repeated for each time point along the time course experiments. The photochemical yield of PSII was calculated as:

$\mathrm{F}_{\mathrm{V}} / \mathrm{F}_{\mathrm{M}}=\left(\mathrm{F}_{\mathrm{M}}-\mathrm{F}_{0}\right) / \mathrm{F}_{\mathrm{M}}$

For each time point we calculated the induction of non-photochemical quenching as: $N P Q=\left(F_{M}-F_{M}{ }^{\prime}\right) / F_{M}{ }^{\prime}$

To estimate the total cumulative non-photochemical down-regulation of PSII across the entire time course we then calculated $\mathrm{NPQ}_{\text {global }}$ as:

$\mathrm{NPQ}_{\text {global }}=\left(\mathrm{F}_{\mathrm{Mm}}-\mathrm{F}_{\mathrm{M}}{ }^{\prime}\right) / \mathrm{F}_{\mathrm{M}}{ }^{\prime}$ 
where $\mathrm{F}_{\mathrm{M}}$ ' was measured under the treatment $\mathrm{HL}$ level and $\mathrm{F}_{\mathrm{Mm}}$ was taken as the highest measurement of $\mathrm{F}_{\mathrm{Mdark}}$ at any point along the time course. This formulation assumes there was no significant culture growth over the course of the time course, which would increase $\mathrm{F}_{\mathrm{Mm}}$ over time.

We determined the effective absorbance cross-section serving PSII photochemistry ( $\sigma_{\text {PSII }}$, $\mathrm{A}^{2}$ quantum $^{-1}$ ) on culture aliquots illuminated by a saturating single turn-over flash of known irradiance (blue LED, 455 $\pm 20 \mathrm{~nm}$; FIRe fluorimeter, Satlantic, Halifax, NS Canada) (Kolber et al. 1998; Barnett 2007). For comparison of the absorbance capacities driving PSII photochemistry and photoinactivation, we estimated an effective absorbance cross section for PSII photoinactivation $\left(\sigma_{\mathrm{i}},\left(\mathrm{A}^{2}\right.\right.$ quantum $\left.\left.^{-1}\right)\right)($ Campbell and Tyystjärvi 2012; Oliver et al. 2003) by plotting the exponential decay of the PSII quantum yield $\mathrm{F}_{V} / \mathrm{F}_{\mathrm{M}}$ in the absence of repair $v s$. the cumulative dose of photons $\mathrm{A}^{-2}$. We estimated the electron transport rate through PSII following (Suggett et al. 2004; Suggett et al. 2009; Huot and Babin 2010) as:

$\mathrm{ETR}=\mathrm{E} \times \sigma_{\mathrm{PSII}} \times \Phi_{\mathrm{PSII}} /\left(\mathrm{F}_{\mathrm{V}} / \mathrm{F}_{\mathrm{M}}\right)$

where $\mathrm{E}$ is the instantaneous irradiance (photons $\left.\mathrm{A}^{-2} \mathrm{~s}^{-1}\right), \Phi_{\mathrm{PSII}}=\left(\mathrm{F}_{\mathrm{M}}{ }^{\prime}-\mathrm{F}_{\mathrm{S}}\right) / \mathrm{F}_{\mathrm{M}}{ }^{\prime}$ is the effective quantum yield for PSII photochemistry measured under irradiance (Genty et al. 1989), and $F_{V} / F_{M}$ is the maximum quantum yield for PSII photochemistry after dark acclimation.

PsbA immunodetection 
The procedure was previously described (Six et al. 2007; Brown et al. 2008). Briefly, cells were harvested on glass fibre filters $(25 \mathrm{~mm}$, Whatman, UK) and the proteins were extracted by one thawing/sonicating round in LDS extraction buffer. The total protein concentration was determined (Lowry protein assay kit, Biorad, CA, USA, with BGG as a protein standard) and $2 \mu \mathrm{g}$ of total protein were loaded on a $4-12 \%$ acrylamide precast NuPAGE gel (Invitrogen, CA, USA), along with PsbA (D1) protein standards (Agrisera, Sweden). Electrophoresis was run for $30 \mathrm{~min}$ at $200 \mathrm{~V}$ and the proteins were transferred to a PVDF membrane. The membranes were immersed in blocking solution (Amersham Biosciences, NJ, USA) for $1 \mathrm{~h}$ and successively incubated with primary antibodies directed against D1 (Agrisera, 1/50,000) in Tween-TBS in the presence of 2\% blocking agent and anti-chicken secondary antibodies coupled with horseradish peroxidase (Biorad, 1/50,000). The membranes were developed by chemoluminescence using ECL Advance (Amersham biosciences) within a CCD imager (FluorSMax, Biorad). Target protein concentrations were determined by fitting the sample signal values on these curves to protein standard curves.

\section{Results and Discussion}

Photosystem II (PSII) function, photoinactivation and repair

In Figure 1 we present time courses for the maximum quantum yield for the PSII pool $\left(\mathrm{F}_{\mathrm{V}} / \mathrm{F}_{\mathrm{M}}\right)(\mathrm{A}, \mathrm{C})$ and for the pool of the key PSII protein PsbA (B, D) for S. costatum (A, B) and P. tricornutum (C, D) shifted from growth under $50 \mu \mathrm{mol}$ photons $\mathrm{m}^{-2} \mathrm{~s}^{-1}\left(\mathrm{~T}_{0}\right)$ up to $450 \mu \mathrm{mol}$ photons $\mathrm{m}^{-2} \mathrm{~s}^{-1}(0-90 \mathrm{~min}$, high light-HL) and then back to growth light of 50 $\mu \mathrm{mol}$ photons $\mathrm{m}^{-2} \mathrm{~s}^{-1}$ for recovery (90-270 min, low light-LL). During the treatments cells 
were incubated in the absence (open symbols) or presence (closed symbols) of lincomycin to inhibit translation of chloroplastic encoded proteins, including $p s b A$ gene, and thereby block the PSII repair cycle. To facilitate comparisons of changes in PSII function and protein content we plotted the data as $\% \mathrm{~T}_{0}$. Both $S$. costatum and $P$. tricornutum showed similar initial $\mathrm{F}_{\mathrm{V}} / \mathrm{F}_{\mathrm{M}}$ values (Table 1), but under LL growth $S$. costatum showed a higher initial level of PsbA protein content, almost twice that of $P$. tricornutum (Table 1), as well as a slightly higher ETR $_{\text {PSII }}(25 \%$, similar as reported before, Lavaud et al. 2007).

During the $\mathrm{HL}$ treatment period, we fitted the decline in $\mathrm{F}_{\mathrm{V}} / \mathrm{F}_{\mathrm{M}}$ in the presence of lincomycin (Figure 1A, C, closed symbols) with a single phase exponential decay to extract a first order rate constant for photoinactivation of PSII in the absence of counteracting repair $\left(\mathrm{k}_{\mathrm{pi}}, \mathrm{s}^{-1}\right)$ (Table 1$)$. These curve fits were not significantly different between $S$. costatum and $P$. tricornutum which therefore showed a common rate constant for photoinactivation under $450 \mu \mathrm{mol}$ photons $\mathrm{m}^{-2} \mathrm{~s}^{-1}$. To generalize this irradiancedependent rate constant to a generalized susceptibility to photoinactivation, we converted $\mathrm{k}_{\mathrm{pi}}$ to a target size formulation (Campbell and Tyystjärvi 2012) of the effective absorbance cross section for photoinactivation, $\sigma_{i}\left(\mathrm{~A}^{2}\right.$ quantum $\left.{ }^{-1}\right)($ Table 1$)($ Oliver et al. 2003; Key et al. 2010; Campbell and Tyystjärvi 2012), giving a value typical for small diatoms (Key et al. 2010; Wu et al. 2011; Wu et al. 2012; Li and Campbell 2013). In parallel, we fitted the decline in PsbA protein in the presence of lincomycin (Figure 1B, D, closed symbols) with single phase exponentials to extract apparent first order rate constant for clearance of PsbA, $\mathrm{k}_{\mathrm{PsbA}}\left(\mathrm{s}^{-1}\right)$ (Table 1) (Wu et al. 2011; Wu et al. 2012). 
Unexpectedly, $\mathrm{k}_{\mathrm{PsbA}}$ was three times lower for $S$. costatum than for P. tricornutum (Table 1).

Over the same initial HL treatment we fitted $\mathrm{F}_{\mathrm{V}} / \mathrm{F}_{\mathrm{M}}$, our measure of the pool of [PSII $\left.{ }_{\text {Active }}\right]$ from the cultures treated in the absence of lincomycin (Figures 1A, C, open symbols) following (Kok 1956; Oliver et al. 2003):

$\mathrm{F}_{\mathrm{V}} / \mathrm{F}_{\mathrm{M}} \mathrm{t}=\mathrm{F}_{\mathrm{V}} / \mathrm{F}_{\mathrm{M}} \mathrm{x}\left(\left(\mathrm{k}_{\mathrm{rec}}+\left(\mathrm{k}_{\mathrm{pi}} \mathrm{x}\left(\left(\exp \left(-\left(\mathrm{k}_{\mathrm{pi}}+\mathrm{k}_{\mathrm{rec}}\right) \mathrm{xt}\right)\right)\right)\right)\right) /\left(\mathrm{k}_{\mathrm{pi}}+\mathrm{k}_{\mathrm{rec}}\right)\right)$

where $\mathrm{F}_{\mathrm{V}} / \mathrm{F}_{\mathrm{M}} \mathrm{t}$ was measured at treatment time $t, \mathrm{~F}_{\mathrm{V}} / \mathrm{F}_{\mathrm{M}}$ was the initial pre-treatment, maximal level of $\mathrm{F}_{\mathrm{V}} / \mathrm{F}_{\mathrm{M}}$ measured after 10 min of dark adaptation from the growth LL, $\mathrm{k}_{\mathrm{pi}}$ was imported from the single phase exponential fits in the presence of lincomycin, and $\mathrm{k}_{\mathrm{rec}}$ was fit as the apparent first order rate constant for repair of photoinactivated PSII $\left[\mathrm{PSII}_{\text {Inactive }] \text { to }[\mathrm{PSII}}\right.$ Active $]$.

During the succeeding LL recovery period, we assumed the PSII photoinactivation rate constant fell to near $0\left(\sigma_{\mathrm{i}} \mathrm{x} \mathrm{I} \sim 0\right)$ and followed (Oliver et al. 2003) to fit $\mathrm{F}_{\mathrm{V}} / \mathrm{F}_{\mathrm{M}}$ as:

$F_{V} / F_{M} r=F_{V} / F_{M} i+\left\{\left(F_{V} / F_{M} m-F_{V} / F_{M} i\right\} x\left(1-e^{-k r e c ~ x t}\right)\right.$

where $F_{\mathrm{V}} / \mathrm{F}_{\mathrm{M}} \mathrm{r}$ was measured at recovery time $\mathrm{r}, \mathrm{F}_{\mathrm{V}} / \mathrm{F}_{\mathrm{M}} \mathrm{i}$ was the maximally inhibited $\mathrm{F}_{\mathrm{V}} / \mathrm{F}_{\mathrm{M}}$ measured at the start of the recovery period, coincident with the end of the $\mathrm{HL}$ treatment period, $\mathrm{F}_{\mathrm{V}} / \mathrm{F}_{\mathrm{M}} \mathrm{m}$ was the maximal $\mathrm{F}_{\mathrm{V}} / \mathrm{F}_{\mathrm{M}}$ measured during the time course. These formulations follow the assumptions of (Kok 1956) that the rate of PSII recovery depends upon accumulated [PSII ${ }_{\text {Inactive }}$, and that drops in $\mathrm{F}_{\mathrm{V}} / \mathrm{F}_{\mathrm{M}}$ reflect drops in $\left[\mathrm{PSII}_{\text {Active }}\right.$ (Wu et al. 2012), mirrored by increases in [PSII $\left.{ }_{\text {Inactive }}\right]$. Although these fits generated good approximations of the experimental data, they contained surprises; the 
apparent $\mathrm{k}_{\mathrm{rec}}$ estimates were far higher than the measured $\mathrm{k}_{\mathrm{PsbA}}$ (Table 1) for clearance of photoinactivated PsbA protein, particularly for S. costatum. Furthermore, during the LL recovery period, $S$. costatum showed an increase in its pool of PsbA protein (Fig. 1B, open squares), while $P$. tricornutum showed no increase in PsbA pool (Fig. 1D, open circles) even though $\mathrm{F}_{\mathrm{V}} / \mathrm{F}_{\mathrm{M}}$ recovered over the same period (Fig. 1C, open circles). Since clearance of photoinactivated PsbA is a key step in the PSII repair cycle, we sought to reconcile these discrepancies.

The models stemming from (Kok 1956), including (Oliver et al. 2003; Lee et al. 2001)

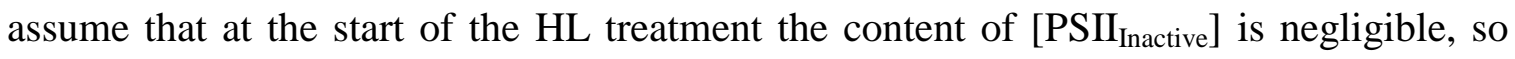
that the $\left[\mathrm{PSII}_{\text {Inactive }}\right]$ substrate for repair accumulates only during the HL treatment period, enabling the repair process parameterized by $\mathrm{k}_{\mathrm{rec}}$ to start action upon the accumulating pool of $\left[\mathrm{PSII}_{\text {Inactive }}\right]$. If the light level is not excessive, at some point, loss of $\left[\mathrm{PSII}_{\text {Active }}\right]$

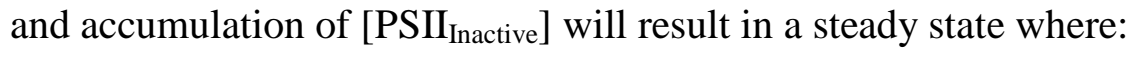

$\left[\mathrm{PSII}_{\text {Active }}\right] \times \mathrm{k}_{\mathrm{pi}}=[\mathrm{PSII}$ Inactive $] \times \mathrm{k}_{\mathrm{rec}}$

In marine diatoms, this assumption of a negligible initial content of $\left[\mathrm{PSII}_{\text {Inactive }}\right]$ may not be generally true (Wu et al. 2011; Wu et al. 2012), since even under low light growth, the cells may retain a significant pool of PSII repair cycle intermediates awaiting recycling into $\left[\mathrm{PSII}_{\mathrm{Active}}\right]$ (Campbell et al. 2013). In this case, the model fit generates an exaggerated estimate for $\mathrm{k}_{\mathrm{rec}}$ because the initial [PSII Inactive] $_{\text {is }}$ larger than assumed by the model. To test this possibility, we had a direct measure of $\mathrm{k}_{\mathrm{pi}}\left(\mathrm{s}^{-1}\right)$ (Table 1) from our lincomycin treated cultures, and we had $\mathrm{k}_{\mathrm{PsbA}}\left(\mathrm{s}^{-1}\right)$ (Table 1) for clearance of PsbA 
protein, as a proxy for the rate-limiting step in the overall PSII repair cycle in diatoms (Campbell et al. 2013). Therefore, we rearranged the steady state equation to: $\mathrm{k}_{\mathrm{PsbA}} / \mathrm{k}_{\mathrm{pi}}=\left[\mathrm{PSII}_{\mathrm{Active}}\right] /\left[\mathrm{PSII} I_{\text {Inactive }}\right]$ This allowed us to estimate $\left[\mathrm{PSII}_{\text {Active }}\right] /\left[\mathrm{PSII}_{\text {Inactive }}\right]$ for the HL steady state condition (Table 1), which we reached within our 90 min incubation under $450 \mu$ mol photons $\mathrm{m}^{-2} \mathrm{~s}^{-}$ ${ }^{1}$ (Figure 1). We then used the measured drop in $F_{V} / F_{M}$ as a proxy for the decline in $\left[\mathrm{PSII}_{\text {Active }}\right.$ (Vassiliev et al. 1994; Wu et al. 2012) (Fig. 1A, C, open symbols) from $\mathrm{T}_{0}$ to the steady state level, to backcast to the estimated $\left[\mathrm{PSII}_{\mathrm{Active}}\right] /\left[\mathrm{PSII} \mathrm{I}_{\text {nactive }}\right]$ under growth LL conditions (Table 1), at 0.29 ([PSII $\left._{\text {Active }}\right] \sim 22 \%$ of PSII Total $)$ for $S$. costatum, and 0.94 ([PSII Active $] 48 \%$ of $\left.\mathrm{PSII}_{\text {Total }}\right)$ for P. tricornutum. These estimates reconcile the apparent discrepancy that upon an upward shift in light S. costatum suffered a smaller drop in PSII function $\left(\mathrm{F}_{\mathrm{V}} / \mathrm{F}_{\mathrm{M}}\right)$, even though its capacity to clear PsbA protein was lower than in $P$. tricornutum. S. costatum started HL treatment with a larger initial reservoir of PSII Inactive, awaiting reassembly into $\mathrm{PSII}_{\text {Active. }}$ This difference between the strains was consistent with the higher initial content of PsbA protein in S. costatum (Table 1), since our detection of PsbA protein includes both PsbA from PSII $_{\text {Active }}$ and PsbA from PSII complexes that have been photoinactivated but which are awaiting disassembly (Campbell et al. 2013). In combination with similar findings from the diatoms Thalassiosira pseudonana and Coscinodiscus radiatus (Wu et al. 2011; Wu et al. 2012), we suggest this pattern of a reservoir of PSII Inactive is a common feature buffering PSII dynamics in marine diatoms (Behrenfeld et al. 1998), particularly in strains such as $S$. costatum with, compared to $P$. tricornutum, a relatively limited capacity for nonphotochemical dissipation of excess excitation energy within PSII, including NPQ and 
PSII cyclic electron transfer (PSII CET) (Lavaud et al. 2004; Lavaud et al. 2007; Lavaud and Lepetit 2013).

In Figure 2, we present a conceptual summary of these arguments. The dotted lines define thresholds for the PSII repair capacity, measured as the $\mathrm{k}_{\mathrm{PsbA}}\left(\mathrm{s}^{-1}, \mathrm{Y}\right.$ axis) required to maintain a given steady state $\left[\mathrm{PSII}_{\mathrm{Total}}\right] /\left[\mathrm{PSII}_{\mathrm{Active}}\right]$ cellular content $(\mathrm{X}$ axis), at a given rate constant $\mathrm{k}_{\mathrm{pi}}\left(\mathrm{s}^{-1}\right)$ for photoinactivation provoked by light level, $\mathrm{E}$ :

$\mathrm{k}_{\mathrm{PsbA}} / \mathrm{k}_{\mathrm{pi}}=\left[\mathrm{PSII}_{\mathrm{Active}}\right] /\left[\mathrm{PSII} I_{\text {Inactive }}\right]$

$\mathrm{k}_{\mathrm{PsbA}}=\left\{\left[\mathrm{PSII}_{\text {Active }}\right] /\left[\mathrm{PSII}_{\text {Inactive }}\right]\right\} \times \mathrm{k}_{\mathrm{pi}}$

$\mathrm{k}_{\mathrm{PsbA}}=\left\{\left[\mathrm{PSII}_{\text {Active }}\right] /\left[\mathrm{PSII}_{\text {Inactive }}\right]\right\} \times\left(\sigma_{\mathrm{i}} \times \mathrm{E}\right)$

$\mathrm{k}_{\mathrm{PsbA}}=\left\{\left(\left[\mathrm{PSII}_{\mathrm{Total}}\right] /\left[\mathrm{PSII}_{\mathrm{Active}}\right]\right)-1\right\}^{-1} \times\left(\sigma_{\mathrm{i}} \times \mathrm{E}\right)$

The fine dotted line defines the threshold for cells when $\mathrm{E}$ is a low light of $50 \mu \mathrm{mol}$ photons $\mathrm{m}^{-2} \mathrm{~s}^{-1}$, near the bottom of the photic zone, or at dawn or dusk. Under low light, photoinactivation is slow, and the cells require only a low capacity to remove photoinactivated PsbA proteins $\left(\mathrm{k}_{\mathrm{Psb}}\right)$ in the PSII repair cycle, in order to maintain a given $\left[\mathrm{PSII}_{\text {Total }}\right] /\left[\mathrm{PSII}_{\text {Active }}\right]$. The dashed line defines the threshold for cells under a moderately high light of $450 \mu \mathrm{mol}$ photons $\mathrm{m}^{-2} \mathrm{~s}^{-1}$, equivalent to the upper $30 \%$ of the photic zone. Under this high light the rate of photoinactivation is faster, and to maintain a

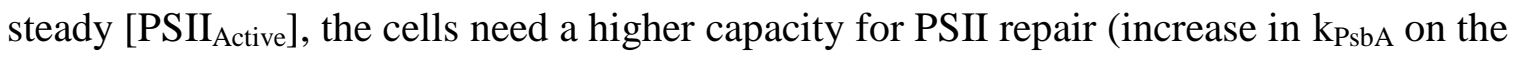
$\mathrm{Y}$ axis) or must accumulate a larger [PSII ${ }_{\text {Total }}$ (shift to the right on the $\mathrm{X}$ axis). If the cells fall below the threshold, they suffer net photoinactivation of the PSII pool, driving $\left[\mathrm{PSII}_{\mathrm{Total}}\right] /\left[\mathrm{PSII}_{\mathrm{Active}}\right]$ to the right until they reach or surpass the threshold. Alternately, cells below the threshold can induce more rapid PSII repair with a higher $\mathrm{k}_{\mathrm{PsbA}}$, or 
possibly induce protective screening or dissipatory mechanisms (NPQ and/or PSII CET for instance) to increase their tolerance threshold by slowing the rate of PSII photoinactivation under a given light level. These threshold lines are related to $\mathrm{E}_{\mathrm{MAX}}$ estimates (Neale et al. 2014) of the maximum tolerable irradiance before the onset of net photoinhibition.

Our measurement of $\mathrm{k}_{\mathrm{PsbA}}$ was made upon cells treated under $450 \mu \mathrm{mol}$ photons $\mathrm{m}^{-2} \mathrm{~s}^{-1}$, but grown under $50 \mu \mathrm{mol}$ photons $\mathrm{m}^{-2} \mathrm{~s}^{-1} . S$. costatum (squares) achieved a $\mathrm{k}_{\mathrm{PsbA}}$ of $3.8 \mathrm{x}$ $10^{-5} \mathrm{~s}^{-1}$ within 30-90 min of the shift to HL. For growth under LL, this $\mathrm{k}_{\mathrm{PsbA}}$ combined with a $\left[\mathrm{PSII}_{\text {Total }}\right] /\left[\mathrm{PSII}_{\text {Active }}\right]$ of $\sim 4.5$ to place the cells well above their tolerance threshold (Fig. 2, fine dotted line), with ample reserve capacity to tolerate an upward fluctuation in light. Upon the shift to HL, S. costatum shifted towards a yet higher $\left[\mathrm{PSII}_{\text {Total }}\right]$ / $\left[\mathrm{PSII}_{\text {Active }}\right]$, to move to the new threshold (Fig. 2, dashed line). P. tricornutum showed a much higher $\mathrm{k}_{\mathrm{PsbA}}$ and a corresponding lower initial $\left[\mathrm{PSII}_{\text {Total }}\right] /\left[\mathrm{PSII}_{\mathrm{Active}}\right]$, which shifted only slightly upwards upon the upward shift in light.

Non-photochemical Chl fluorescence quenching (NPQ)

In Figure 3 we present time courses for induction of NPQ. Figures 3A and 3C compare the development of NPQ, tracking down regulation of PSII relative to $F_{M}$ measured for each time point after $5 \mathrm{~min}$ in the dark, prior to measurement of $F_{M}$ d during re-exposure to the treatment light. S. costatum (Fig. 3A, open squares) showed a progressive induction of NPQ, with subsequent partial relaxation during LL recovery, consistent with a readily reversible NPQ mechanism. This induction was inhibited when chloroplastic protein 
synthesis was inhibited by lincomycin (Fig. 3A, closed squares). P. tricornutum showed a higher initial NPQ as reported previously (Lavaud et al. 2004; Lavaud et al. 2007; Lavaud and Lepetit 2013), but no further increase over the course of the HL treatment. Instead, during subsequent LL recovery, $P$. tricornutum showed a large accumulation of NPQ (Fig. 3C, open circles). Again, inhibition of chloroplastic protein synthesis by lincomycin blocked NPQ induction (Fig. 3C, closed circles).

We also estimated $\mathrm{NPQ}_{\text {global, }}$ the cumulative global non-photochemical down regulation of PSII across the experiment time course by comparing $\mathrm{F}_{\mathrm{M}}$ ' measured under illumination at each time point, to the highest level of $\mathrm{F}_{\mathrm{M}}$ achieved by the culture across the entire experiment time course. In the absence of lincomycin $\mathrm{NPQ}_{\text {global }}$ increased significantly during the HL incubation (Fig. 3B, D, open symbols) and relaxed during subsequent LL recovery, particularly in $S$. costatum. Inhibition of chloroplast protein synthesis by lincomycin blocked most (S. costatum; Fig. 3B, closed squares) or all (P. tricornutum, Fig. 3D, closed circles) of this light and time dependent increase. We are as yet unsure whether NPQ and $\mathrm{NPQ}_{\text {global }}$ have direct and specific dependencies upon active chloroplastic protein synthesis, or whether accumulation of $\mathrm{NPQ}_{\text {global }}$ is blocked as a secondary effect of the blockage of the PSII repair cycle by lincomycin. The two species both achieved comparable peak levels of $\mathrm{NPQ}_{\text {global }}$ after 60-90 min of higher light incubation, i.e. NPQ $\sim 1.4$, a value similar to previous reports for $P$. tricornutum but higher for S. costatum (Lavaud et al. 2007), likely due to a higher DT content (see Lavaud and Lepetit 2013). The NPQ induction was nevertheless significantly more sustained in P. tricornutum (Fig. 3C), both during and subsequent to HL incubation. 
These patterns are consistent with the studies showing induction of sustained quenching centres under prolonged HL exposure in $P$. tricornutum (i.e. persistence of a higher number of Q1 NPQ sites due to the persistence of DT molecules in the PSII LHC antenna) (see Lavaud and Goss 2014).

$\sigma_{P S I}$, the effective absorbance cross section serving PSII photochemistry

$\sigma_{\mathrm{PSII}}$ measured in dark-adapted samples was initially similar in the two species as reported before under similar growth conditions, (Lavaud et al. 2007), at $253 \mathrm{~A}^{2}$ quantum $^{-1}$ (95\% C.I. \pm 5) for $S$. costatum and $267 \mathrm{~A}^{2}$ quantum $^{-1}(95 \%$ C.I. \pm 10$)$ for P. tricornutum (Table 1, Figure 4A, B, open symbols) when measured using the blue excitation LED of the FIRe fluorometer. When chloroplastic protein synthesis was running, the PSII repair cycle was operational, and both species were able to induce NPQ (Fig. 3), they held $\sigma_{\text {PSII }}$ steady over the course of HL treatment and LL recovery, (Figure 4A, B, open symbols) even though $P$. tricornutum suffered a $25 \%$ drop in $\mathrm{F}_{\mathrm{V}} / \mathrm{F}_{\mathrm{M}}$ and subsequent recovery over this time period.

In contrast, when lincomycin was added, $\sigma_{\mathrm{PSII}}$ increased significantly over the course of the HL treatment, with only variable decline during the subsequent LL recovery period. This increase was consistent with some antenna connectivity, so that as PSII centres were inactivated, their antenna capacity was left to increase the $\sigma_{\mathrm{PSII}}$ of the remaining PSII active centres. Interestingly, the connectivity parameter $\rho$ extracted from the fluorescence induction curves used to estimate $\sigma_{\mathrm{PSII}}$ was near zero in $P$. tricornutum $(0.02 \pm 0.03)$ but significant in $S$. costatum $(0.16 \pm 0.08)$, consistent with the more effective control of excitation energy by NPQ in $P$. tricornutum, as long as PSII repair was active. The 
increase in dark $\sigma_{\text {PSII }}$ was also consistent with the inhibition of NPQ induction in the presence of lincomycin, so that in the absence of lincomycin, an increase in NPQ (Figure 3 , open symbols) countered the tendency towards an increase in $\sigma_{\text {PSII }}$ whereas in the presence of lincomycin, loss of NPQ capacity allows $\sigma_{\text {PSII }}$ to increase excessively as PSII centres became photoinactivated.

After growth and treatment of P. tricornutum at higher lights Koblizek et al. (2001) found a strong correlation between induction of NPQ and a decrease in $\sigma_{\text {PSII }}$ for red light. Their conditions of higher growth and treatment lights were sufficient to drive NPQ to $\sim 1.7$ within $100 \mathrm{~s}$, whereas our lower light cultures and treatments did not reach that level of NPQ within $3600 \mathrm{~s}$ of treatment. Koblizek et al. (2001) finding's are thus consistent with our works (Lavaud et al. 2002; Ruban et al. 2004) on the fast NPQ induction in $P$. tricornutum under higher light, where recent NPQ model (Chukhutsina et al. 2014; Lavaud and Goss 2014; Goss and Lepetit 2015) predict that detachment of FCP units from PSII (Q1 quenching site) should decrease $\sigma_{\text {PSII. }}$

Figure 5 summarizes these critical interactions among PSII repair, NPQ and control of excitation delivery to PSII under moderately high light. In S. costatum cells with some connectivity across the PSII antenna bed, inhibition of the PSII repair cycle and parallel limitation on the induction of NPQ (Fig. 5A, closed squares) suffered large increases in the $\sigma_{\mathrm{PSII}}$ measured under treatment irradiance. In $P$. tricornutum, with little connectivity across the PSII antenna bed, and higher basal NPQ, cells were able to maintain better control of $\sigma_{\text {PSII }}$, even in the face of inhibition of the PSII repair cycle. We connect these patterns back to our estimates of $\left[\mathrm{PSII}_{\text {Total }}\right] /\left[\mathrm{PSII}_{\text {Active }}\right]$, showing that the general strong 
NPQ capacities of $P$. tricornutum confer a lower-cost PSII repair cycle upon the cells (Fig. 2), since they can maintain their [PSII Active $_{\text {with a smaller pool of }[\mathrm{PSII}}$ Total $]$, even in the face of upward fluctuations in light. Such feature fits very well with the adaptation of P. tricornutum to a highly fluctuating light climate regularly punctuated with excess light exposures as encountered in its original habitat (Lavaud et al. 2007; Lavaud and Lepetit 2013). This is in contrast to $S$. costatum which originates from a habitat where light changes are slower and of lower amplitude (Lavaud et al. 2007; Lavaud and Lepetit 2013). The present work further confirms the important role for the light-dependent fast regulation of photochemistry by NPQ in coordination with PsbA synthesis and PSII repair cycle capacity in the ecophysiology of both pennate and centric diatoms (Key et al. 2010; Wu et al. 2011; Wu et al. 2012). It supports the ecological diversity of diatoms as well as their ubiquity and ecological success in modern oceans (Armbrust 2009; Kooistra et al. 2007; Mock and Medlin 2012).

\section{References}

Armbrust EV (2009) The life of diatoms in the world's oceans. Nature 459:185-192

Bailleul B, Rogato A, de Martino A, Coesel S, Cardol P, Bowler C, Falciatore A, Finazzi G (2010) An atypical member of the light-harvesting complex stress-related protein family modulates diatom responses to light. Proc Natl Acad Sci USA $107: 18214-18219$

Barnett A, Méléder V, Blommaert L, Lepetit B, Gaudin P, Vyverman W, Sabbe K, Dupuy C, Lavaud J (2015) Growth form defines physiological photoprotective capacity in intertidal benthic diatoms. ISME J 9:32-45 
Barnett AB (2007) Fireworx.

Behrenfeld MJ, Prasil O, Kolber ZS, Falkowski PG (1998) Compensatory changes in Photosystem II electron turnover rates protect photosynthesis from photoinhibition. Photosynth Res 58:259-268

Blanchard GF, Guarini J-M, Dang C, Richard P (2004) Characterizing and quantifying photoinhibition in intertidal microphytobenthos. J Phycol 40:692-696

Brown C, MacKinnon J, Cockshutt AM, Villareal T, Campbell DA (2008) Flux capacities and acclimation costs in Trichodesmium from the Gulf of Mexico. Mar Biol 154:413-422

Brunet C, Lavaud J (2010) Can the xanthophyll cycle help extract the essence of the microalgal functional response to a variable light environment ? . J Plankton Res $32: 1609-1617$

Büchel C (2014) Fucoxanthin-chlorophyll-proteins and non-photochemical fluorescence quenching of diatoms. In: Demmig-Adams B, Garab G, Adams WWI, Govindjee (eds) Non-Photochemical Fluorescence Quenching and Energy Dissipation In Plants, Algae and Cyanobacteria. Springer, Dordretch, The Netherlands,

Campbell DA, Hossain Z, Cockshutt AM, Zhaxybayeva O, Wu H, Li G (2013) Photosystem II protein clearance and FtsH function in the diatom Thalassiosira pseudonana. Photosynth Res 115:43-54

Campbell DA, Tyystjärvi E (2012) Parameterization of photosystem II photoinactivation and repair. Biochim Biophys Acta 1817:258-265 
Chukhutsina, VU, Büchel C, van Amerongen H (2014) Disentangling two nonphotochemical quenching processes in Cyclotella meneghiniana by spectrallyresolved picosecond fluorescence at $77 \mathrm{~K}$. Biochim Biophys Acta 1837:899-907

Consalvey MC, Paterson DM, Underwood GJC (2004) The ups and downs of life in a benthic biofilm: migration of benthic diatoms. Diatom Res 19:181-202

Depauw FA, Rogato A, d'Alcala MR, Falciatore A (2012) Exploring the molecular basis of responses to light in marine diatoms. J Exp Bot 63:1575-1591

Derks A, Schaven K, Bruce D (2015) Diverse mechanisms for photoprotection in photosynthesis. Dynamic regulation of photosystem II excitation in response to rapid environmental change. Biochim Biophys Acta 1847:468-485

Dimier C, Corato F, Tramontano F, Brunet C (2007) Photoprotective capacity as functional trait in planktonic algae: relationship between xanthophyll cycle and ecological characteristics in three diatoms. J Phycol 43:937-947

Genty B, Briantais J-M, Baker NR (1989) The relationship between the quantum yield of photosynthetic electron transport and quenching of chlorophyll fluorescence. Biochim Biophys Acta 990:87-92

Giovagnetti V, Flori S, Tramontano F, Lavaud J, Brunet C (2014) The velocity of light intensity increase modulates the photoprotective response in coastal diatoms. PloS ONE 9:e103782

Goss R, Lepetit B (2015) Biodiversity of NPQ. J Plant Physiol 172:15-32

Huot Y, Babin M (2010) Overview of Fluorescence Protocols: Theory, Basic Concepts, and Practice. In: Suggett DJ, Prášil O, Borowitzka MA (eds) Chlorophyll $a$ Fluorescence in Aquatic Sciences: Methods and Applications., vol 4. 
Development In Applied Phycology. Springer, Dordrecht, The Netherlands, pp $31-74$

Juneau P, Barnett A, Méléder V, Dupuy C, Lavaud J (2015) Combined effect of high light and high salinity on the regulation of photosynthesis in three diatom species belonging to the main growth forms of intertidal flat inhabiting microphytobenthos. J Exp Mar Biol Ecol 463:95-104

Key T, McCarthy A, Campbell DA, Six C, Roy S, Finkel ZV (2010) Cell size trade-offs govern light exploitation strategies in marine phytoplankton. Environ Microbiol 12:95-104

Kobližek M, Kaftan D, Nedbal L (2001) On the relationship between the nonphotochemical quenching of the chlorophyll fluorescence and the Photosystem II light harvesting efficiency. A repetitive flash fluorescence induction study. Photosynth Res 68: 141-152.

Kok B (1956) On the inhibition of photosynthesis by intense light. Biochim Biophys Acta 21:234-244

Kolber ZS, Prášil O, Falkowski PG (1998) Measurements of variable chlorophyll fluorescence using fast repetition rate techniques: defining methodology and experimental protocols. Biochim Biophys Acta 1367:88-106

Kooistra WHCF, Gersonde R, Medlin LK, Mann DG (2007) The origin and the evolution of the diatoms: Their adaptation to a planktonic existence. In: Falkowski PG, Knoll AH (eds) Evolution of Primary Producers in the Sea. Elsevier Academic Press, Burlington, pp 207-249 
Kropuenske LR, Mills MM, van Dijken GL, Bailey S, Robinson DH, Welschmeyer NA, Arrigo KR (2009) Photophysiology in two major Southern Ocean phytoplankton taxa: Photoprotection in Phaeocystis antartica and Fragilaria cylindricus. Limnol Oceanogr 54:1176-1196

Lavaud J, Goss R (2014) The peculiar features of non-photochemical fluorescence quenching in diatoms and macrophytic brown algae. In: Demmig-Adams B, Garab G, Adams WWI, Govindjee (eds) Non-Photochemical Fluorescence Quenching and Energy Dissipation In Plants, Algae and Cyanobacteria, vol 40. Advances in Photosynthesis and Respiration. Springer, Dordretch, The Netherlands, pp 421-443

Lavaud J, Lepetit B (2013) An explanation for the inter-species variability of the photoprotective non-photochemical chlorophyll fluorescence quenching in diatoms. BBA Bioenergetics 1827:294-302

Lavaud J, Rousseau B, Etienne A-L (2004) General features of photoprotection by energy dissipation in planktonic diatoms (Bacillariophyceae). J Phycol 40:130-137

Lavaud J, Strzepek RF, Kroth PG (2007) Photoprotection capacity differs among diatoms: Possible consequences on the spatial distribution of diatoms related to fluctuations in the underwater light climate. Limnol Oceanogr 52:1188-1194

Lavaud J, van Gorkom H, Etienne A-L (2002) Influence of the diadinoxanthin pool size on phototoprotection in the marine planktonic diatom Phaeodactylum tricornutum. Plant Physiol 129:1398-1406

Laviale M, Barnett A, Ezequiel J, Lepetit B, Frankenbach S, Méléder M, Serôdio J, Lavaud J (2015) Response of intertidal benthic microalgal biofilms to a coupled 
light-temperature stress: evidence for latitudinal adaptation along the Atlantic coast of Southern Europe. Environ Microbiol In press:doi:10.1111/14622920.12728

Lee HY, Hong YN, Chow WS (2001) Photoinactivation of photosystem II complexes and photoprotection by non-functional neighbours in Capsicum annuит L leaves. Planta 212:332-342

Li G, Campbell DA (2013) Rising $\mathrm{CO}_{2}$ interacts with growth light and growth rate to alter photosystem II photoinactivation of the coastal diatom Thalassiosira pseudonana. PLoS ONE 8:e55562

Lyon, Mock T (2014) Polar microalgae: New approaches towards understanding adaptations to an extreme and changing environment. Biology 3:58-80

MacIntyre HL, Kana TM, Geider RJ (2000) The effect of water motion on short-term rates of photosynthesis by marine phytoplankton. Trends Plant Sci 5:12-17

Mills MM, Kropuenske LR, van Dijken GL, Alderkamp A-C, Berg GM, Robinson DH, Welschmeyer NA, Arrigo KR (2010) Photophysiology in two Southern ocean phytoplankton taxa: Photosynthesis of Phaeocystis antarctica (Prymnesiophyceae) and Fragilaria cylindrus (Bacillariophyceae) under simulated mixed-layer irradiance. J Phycol 46:1114-1127

Mock T, Medlin LK (2012) Genomics and genetics of diatoms. Adv Bot Res 64:245-284

Neale PJ, Pritchard AL, Ihnacik R (2014) UV effects on the primary productivity of picophytoplankton: biological weighting functions and exposure response curves of Synechococcus. Biogeosciences 11:2883-2895 
Obata T, Fernie AR, Nunes-Nesi A (2013) The central carbon and energy metabolism of marine diatoms. Metabolites 325-346

Oliver RL, Whittington J, Lorenz Z, Webster IT (2003) The influence of vertical mixing on the photoinhibition of variable chlorophyll $a$ fluorescence and its inclusion in a model of phytoplankton photosynthesis. J Plankton Res 25:1107-1129

Petrou K, Doblin MA, Ralph PJ (2011) Heterogeneity in the photoprotective capacity of three Antarctic diatoms during short-term changes in salinity and temperature. Mar Biol 158:1029-1041

Petrou K, Hill R, Brown CM, Campbell AD, Doblin MA, Ralph PJ (2010) Rapid photoprotection in sea-ice diatoms from the East Antarctic pack ice. Limnol Oceanogr 55:1400-1407

Raven JA (2011) The cost of photoinhibition. Physiol Plantarum 142:87-104

Ruban AV, Lavaud J, Rousseau B, Guglielmi G, Horton P, Etienne A-L (2004) The super excess energy dissipation in diatom algae: comparative analysis with higher plants. Photosynth Res 82:165-175

Sarthou G, Timmermans KR, Blain S, Tréguer P (2005) Growth physiology and fate of diatoms in the ocean: a review. J Sea Res 53:25-41

Six C, Finkel ZV, Irwin AJ, Campbell DA (2007) Light variability illuminates nichepartitioning among marine picocyanobacteria. PLoS ONE 2:e1341

Strzepek RF, Harrison PJ (2004) Photosynthetic architecture differs in coastal and oceanic diatoms. Nature 431:689-692 
Suggett DJ, MacIntyre HL, Geider RJ (2004) Evaluation of biophysical and optical determinations of light absorption by photosystem II in phytoplankton. Limnol Oceanogr Methods 2:316-332

Suggett DJ, MacIntyre HL, Kana TM, Geider RJ (2009) Comparing electron transport with gas exchange: parameterising exchange rates between alternative photosynthetic currencies for eukaryotic phytoplankton. Aquat Microb Ecol $56: 147-162$

Tréguer P, De La Rocha CL (2013) The world ocean silica cycle. Ann Rev Mar Sci 5:477-501

van de poll WH, Lagunas M, de Vries T, Visser RJW, Buma AGJ (2011) Nonphotochemical quenching of chlorophyll fluorescence and xanthophyll cycle responses after excess PAR and UVR in Chaetoceros brevis, Phaeocystis antarctica and coastal Antarctic phytoplankton. Mar Ecol Prog Ser 426:119-131

Vassiliey IR, Prasil O, Wyman KD, Kolber Z, Hanson, Jr. AK, Prentice JE, Falkowski PG (1994) Inhibition of PS II photochemistry by PAR and UV radiation in natural phytoplankton communities. Photosynth Res 42: 51--64, 1994.

Wagner H, Jakob T, Wilhelm C (2006) Balancing the energy flow from captured light to biomass under fluctuating light conditions. New Phytol 169:95-108

Wilhelm C, Jungandreas A., Jakob T., G. R (2014) Light acclimation in diatoms: From phenomenology to mechanisms. Mar Genom 16:5-15

Wu H, Cockshutt AM, McCarthy A, Campbell AD (2011) Distinctive photosystem II photoinactivation and protein dynamics in marine diatoms. Plant Physiol $156: 2184-2195$ 
Wu H, Roy S, Alami m, Green BR, Campbell AD (2012) Photosystem II photoinactivation, repair, and protection in marine centric diatoms. Plant Physiol $160: 464-476$ 
1 Table 1 Photosystem II (PSII) photoinactivation and repair parameters

\begin{tabular}{|c|c|c|c|c|c|c|c|c|c|c|}
\hline Species & $\mathrm{F}_{\mathrm{V}} / \mathrm{F}_{\mathrm{M}}$ & $\begin{array}{l}\sigma_{\text {PSII }} \\
\left(\mathrm{A}^{2}\right. \\
\left.\text { quantum }^{1}\right)\end{array}$ & $\begin{array}{l}\text { ETR }_{\text {PSII }} \\
\left(\mathrm{e}^{-} \mathrm{PSII}^{-1} \mathrm{~s}^{-1}\right)\end{array}$ & $\begin{array}{l}\mathrm{k}_{\mathrm{pi}} \\
\left(\mathrm{s}^{-1}\right)\end{array}$ & $\begin{array}{l}\sigma_{i} \\
\left(\mathrm{~A}^{2}\right. \\
\left.\text { quantum }^{-1}\right)\end{array}$ & $\mathrm{K}_{\mathrm{PsbA}}\left(\mathrm{s}^{-1}\right)$ & $\mathrm{k}_{\mathrm{rec}}\left(\mathrm{s}^{-1}\right)$ & 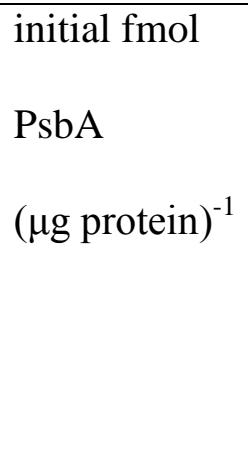 & $\begin{array}{l}\text { HL steady } \\
\text { state } \\
{\left[\mathrm{PSII}_{\text {Active }}\right] /} \\
{\left[\mathrm{PSII}_{\text {Inactive }}\right]} \\
=\mathrm{K}_{\mathrm{PsbA}} / \mathrm{k}_{\mathrm{pi}}\end{array}$ & $\begin{array}{l}\text { Growth LL } \\
{\left[\mathrm{PSII}_{\text {Active }}\right] /} \\
{\left[\mathrm{PSII}_{\text {Inactive }}\right]}\end{array}$ \\
\hline$S c$ & $\begin{array}{l}0.67 \\
\pm 0.03\end{array}$ & $253 \pm 5$ & $252 \pm 25$ & $\begin{array}{l}1.6 \times 10^{-4} \\
\pm 3 \times 10^{-5}\end{array}$ & $\begin{array}{l}6.1 \times 10^{-5} \\
\pm 1.1 \times 10^{-25}\end{array}$ & $\begin{array}{l}3.8 \times 10^{-5} \\
\pm 2.7 \times 10^{-5}\end{array}$ & $\geq 2.1 \times 10^{-3}$ & $65 \pm 19$ & 0.24 & $\sim 0.29$ \\
\hline$P t$ & $\begin{array}{l}0.67 \\
\pm 0.003\end{array}$ & $267 \pm 10$ & $201 \pm 7$ & & & $\begin{array}{l}1.1 \times 10^{-4} \\
\pm 6.6 \times 10^{-5}\end{array}$ & $\begin{array}{l}5.4 \times 10^{-4} \\
\pm 1.9 \times 10^{-4}\end{array}$ & $38 \pm 6.8$ & 0.69 & $\sim 0.94$ \\
\hline
\end{tabular}

2

$3 S c$, Skeletonema costatum; Pt, Phaeodactylum tricornutum; $\mathrm{F}_{\mathrm{V}} / \mathrm{F}_{\mathrm{M}}$, maximum quantum yield of PSII; $\sigma_{\mathrm{PSII}}$, effective absorbance cross

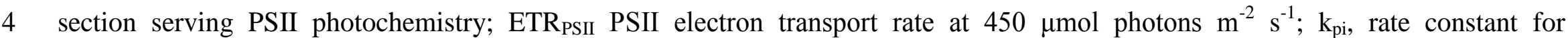

5 photoinactivation of PSII at $450 \mu \mathrm{mol}$ photons $\mathrm{m}^{-2} \mathrm{~s}^{-1} ; \sigma_{\mathrm{i}}$, effective absorbance cross section for photoinactivation of PSII; $\mathrm{k}_{\mathrm{psba}}$, rate

6 constant for clearance of PsbA protein; $\mathrm{k}_{\mathrm{rec}}$, apparent Kok rate constant for recovery of PSII; HL, high light; LL, low light. Parameters

7 are means of measures from three independent cultures, $\pm 95 \%$ C.I. 


\section{Figure legends}

9 Figure 1. Photosystem II (PSII) function and protein dynamics. Maximum quantum yield

10 of PSII photochemistry $\mathrm{F}_{\mathrm{V}} / \mathrm{F}_{\mathrm{M}}(\mathrm{A}, \mathrm{C})$ or PsbA protein content $(\mathrm{B}, \mathrm{D})$ vs. time under 450

11 (0-90 min) or $50 \mu \mathrm{mol}$ photons $\mathrm{m}^{-2} \mathrm{~s}^{-1}$ (90-270 min) in Skeletonema costatum (squares; A,

12 B) or Phaeodactylum tricornutum (circles; C, D) cultures in the absence (open symbols,

13 no lincomycin) or presence (closed symbols, with lincomycin) of PSII repair. $\mathrm{n}=3$

14 independent cultures \pm S.D. $95 \%$ confidence intervals on non-linear regression fits are

15 shown with fine dotted lines. $\mathrm{T}_{0}$ values for $\mathrm{F}_{\mathrm{V}} / \mathrm{F}_{\mathrm{M}}$ and fmol PsbA $\mu$ g protein ${ }^{-1}$ are shown

16 in Table 1.

18 Figure 2. Rate constant, $\mathrm{k}_{\mathrm{PsbA}}\left(\mathrm{s}^{-1}\right)$ for clearance of PsbA protein plotted vs. estimated 19 ratio of $\left[\mathrm{PSII}_{\mathrm{Total}}\right] /\left[\mathrm{PSII}_{\mathrm{Active}}\right]$. $\mathrm{k}_{\mathrm{PsbA}}$ was estimated from the single phase exponential 20 curve fits of the decline in PsbA protein in the presence of lincomycin (Figs. 1B, D).

$21\left[\mathrm{PSII}_{\text {Total }}\right] /\left[\mathrm{PSII}_{\text {Active }}\right]$ was estimated from a simple kinetic model of the PSII repair

22 cycle. $S$ costatum (squares, rightward arrow indicates shift from $50 \mu \mathrm{mol}$ photons $\mathrm{m}^{-2} \mathrm{~s}^{-1}$

23 growth LL up to HL-450 $\mu \mathrm{mol}$ photons $\mathrm{m}^{-2} \mathrm{~s}^{-1}$ ) or P. tricornutum (circles). Dotted lines

24 show the threshold between steady state (below line) maintenance of $\left[\mathrm{PSII}_{\mathrm{Active}}\right]$ and net 25 photoinhibition of PSII (above the line) for $50 \mu \mathrm{mol}$ photons $\mathrm{m}^{-2} \mathrm{~s}^{-1}$ growth LL while the 26 dashed line shows the threshold to maintain a steady $\left[\mathrm{PSII}_{\text {Active }}\right]$ in the face of accelerated 27 photoinactivation under $450 \mu \mathrm{mol}$ photons $\mathrm{m}^{-2} \mathrm{~s}^{-1}$ growth HL.

29 Figure 3. Non-photochemical quenching-NPQ (A, C) and cumulative global NPQ-

$30 \mathrm{NPQ}_{\text {global }}(\mathrm{B}, \mathrm{D})$ vs. time under $450(0-90 \mathrm{~min})$ or $50 \mu \mathrm{mol}$ photons $\mathrm{m}^{-2} \mathrm{~s}^{-1}(90-270 \mathrm{~min})$ 
31 in S. costatum (squares, A, B) or P. tricornutum (circles, C, D) cultures in the absence

32 (open symbols, no lincomycin) or presence (closed symbols, with lincomycin) of PSII

33 repair. $\mathrm{n}=3$ independent cultures \pm S.D.

35 Figure 4. Effective absorbance cross section serving PSII photochemistry $\left(\sigma_{\mathrm{PSII}}\right) v s$. time 36 under $450(0-90 \mathrm{~min})$ or $50 \mu \mathrm{mol}$ photons $\mathrm{m}^{-2} \mathrm{~s}^{-1}$ (90-270 min) in S. costatum (squares,

37 A) or $P$. tricornutum (circles, B) cultures in the absence (open symbols, no lincomycin)

38 or presence (closed symbols, with lincomycin) of PSII repair. $n=3$ independent cultures $39 \pm$ S.D.

40

41 Figure 5. Effective absorbance cross section serving PSII photochemistry ( $\left.\sigma_{\text {PSIII }}{ }^{\prime}\right)$ 42 measured under HL ( $450 \mu \mathrm{mol}$ photons $\left.\mathrm{m}^{-2} \mathrm{~s}^{-1}\right) v s$. NPQ in $S$. costatum (squares, A) or $P$. 43 tricornutum (circles, B) cultures in the absence (open symbols, no lincomycin) or 44 presence (closed symbols, with lincomycin) of PSII repair. Individual paired data points 45 plotted from $\mathrm{n}=3$ independent cultures.

46

47 